\title{
Vapor Pressure Deficit, Temperature, and Light Affect Postharvest Drying of Fraser Fir and Eastern White Pine
}

\author{
L.E. Hinesley ${ }^{1}$ and L.K. Snelling ${ }^{2}$ \\ Department of Horticultural Science, North Carolina State University, \\ Raleigh, NC 27695-7609
}

Additional index words. Abies fraseri, Pinus strobus, postharvest storage, Christmas trees, controlled environment, relative humidity, water stress

Abstract. Branches of Fraser fir [Abies fraseri (Pursh) Poir.] and eastern white pine (Pinus strobus L.) were subjected to various temperatures, vapor pressure deficits (VPD), and light regimes in controlled-environment chambers. Drying rates, based on measurements of needle water potential $(\psi)$, were accelerated by increasing VPD, high temperature, and light. Fraser fir and white pine dried to - 4.0 MPa and - 3.0 MPa, respectively, in about the same time. The relationship of moisture content (MC) to $\psi$ was linear for Fraser fir, quadratic for white pine. The MC of Fraser fir at - 4.0 MPa was also a linear function of VPD during drying. Water loss was greatest early in the drying cycle, and high temperature (25C) promoted rapid drying, even at low VPD.

The "damage threshold" (Montano and Proebsting, 1985) is the MC below which a cut Christmas tree experiences irreversible damage, e.g., accelerated needle loss, dis-

Received for publication 27 July 1990. This research was funded by the North Carolina Agricultural Research Service, Raleigh, NC 276957643. Use of trade names does not imply endorsement of products named nor criticism of similar ones not mentioned. Technical assistance by the staff of the Southeastern Plant Environment Laboratory (Phytotron), N.C. State Univ., Raleigh, is gratefully acknowledged. The cost of publishing this paper was defrayed in part by the payment of page charges. Under postal regulations, this paper therefore must be hereby marked advertisement solely to indicate this fact.

'Associate Professor.

${ }^{2}$ Agricultural Research Technician.

Abbreviations: MC, moisture content; $\psi$, needle water potential; VPD, vapor pressure deficit. coloration, or the tendency to defoliate following dehydration. Trees typically reach this threshold before they reach the "critical moisture content", where they cannot completely rehydrate when the basal stem is recut and placed in water (Van Wagner, 1963). Reported values for the damage threshold are - 3.0 MPa for eastern white pine (Seiler et al., 1988), - 3.5 MPa for Douglas fir [Pseudotsuga mensiesii (Mirb.) France] (Chastagner, 1986; Montano and Proebsting, 1985), - 4.0 MPa for Fraser fir (Hinesley, 1984), and -4.0 to $-4.9 \mathrm{MPa}$ for eastern redcedar (Juniperus virginiana L.) (Hinesley, 1988).

Transpiration is a function of the vapor pressure gradient between leaves and external air (Grange and Hand, 1987; Schulze, 1986). Optimum conditions for postharvest storage of two important Christmas tree species, Fraser fir and eastern white pine, are unknown. In earlier work with Fraser fir
(Mitcham-Butler et al., 1988), high temperatures accelerated drying, but the role of VPD was not separated from that of temperature. Therefore, the objective of this research was to determine the effects of temperature, VPD, and light on postharvest drying of Fraser fir and eastern white pine.

Experiments were carried out in the Southeastern Plant Environment Laboratory, Raleigh, N.C. Plant material consisted of branch tips (secondary and tertiary axes) from the lower crown of 15-year-old, natural-grown Fraser fir and white pines growing at Crossnore, N.C. The fir was in a plantation; the white pine in a windbreak. Each experimental unit consisted of a current-year branch tip (secondary axis) and inserted laterals (tertiary axes), plus a section of 2-year-old internode to serve as a stem. Six vigorous trees (blocks) of each species were selected, and four uniform branches $\approx 0.5 \mathrm{~m}$ long were collected from each tree on each sampling date. Upon severance, branches were immediately stood with bases in tapwater and transported the same day to Raleigh and stored in darkness at $5 \mathrm{C}$. The next day, bases were

Table 1. Treatments used to evaluate postharvest drying of Fraser fir and eastern white pine.

\begin{tabular}{llll}
\hline \hline $\begin{array}{c}\text { Temperature } \\
\left({ }^{\circ} \mathrm{C}\right)\end{array}$ & $\begin{array}{c}\text { Relative } \\
\text { humidity } \\
(\%)\end{array}$ & $\begin{array}{c}\text { Vapor } \\
\text { pressure } \\
(\mathrm{kPa})\end{array}$ & $\begin{array}{c}\text { VPD } \\
(\mathrm{kPa})^{\boldsymbol{x}}\end{array}$ \\
\hline 25 & 25 & 0.79 & 2.36 \\
& 60 -Light & 1.88 & 1.25 \\
& 60-Dark & 1.88 & 1.25 \\
& 90 & 2.82 & 0.32 \\
17.5 & 25 & 0.50 & 1.50 \\
& 60 -Light & 1.20 & 0.80 \\
& 60 -Dark & 1.20 & 0.80 \\
& 90 & 1.79 & 0.21 \\
10 & 25 & 0.30 & 0.92 \\
& $63^{\text {y }}$-Light & 0.76 & 0.45 \\
& $63^{\text {y-Dark }}$ & 0.76 & 0.45 \\
& 90 & 1.09 & 0.12 \\
\hline
\end{tabular}

${ }^{\mathrm{z}} 1.0 \mathrm{kPa}=10 \mathrm{mb}=7.6 \mathrm{~mm} \mathrm{Hg}$.

${ }^{\mathrm{r}}$ Lowest relative humidity that could be constantly maintained with available equipment. 
Table 2. Multiple regression coefficients to estimate $\psi$ and MC (\%) of branches of Fraser fir and eastern white pine during postharvest drying in darkness. ${ }^{z}$

\begin{tabular}{|c|c|c|c|c|}
\hline \multirow{3}{*}{$\begin{array}{l}\text { Term } \\
\text { in } \\
\text { modely }\end{array}$} & \multicolumn{4}{|c|}{ Species } \\
\hline & \multicolumn{2}{|c|}{ Fraser fir } & \multicolumn{2}{|c|}{ White pine } \\
\hline & $\psi^{x}$ & $M C^{x}$ & $\psi$ & $\mathrm{MC}$ \\
\hline Intercept & 0.39 & 138.1 & 0.08 & 159.2 \\
\hline$(V P D)^{-1}(V)$ & 1.31 & -4.09 & -0.34 & -2.85 \\
\hline Temp. (T) & 0.68 & -0.59 & 0.54 & -0.45 \\
\hline Days (D) & 7.26 & -12.73 & 6.00 & -7.40 \\
\hline$D^{2}$ & -0.69 & 1.24 & -0.42 & 0.28 \\
\hline $\mathrm{D}^{3}$ & 0.020 & -0.044 & 0.010 & -0.0038 \\
\hline$T \times V$ & -0.098 & 0.350 & $\ldots$ & 0.36 \\
\hline $\mathrm{D} \times \mathrm{V}$ & -0.38 & 1.53 & 0.45 & 0.982 \\
\hline $\mathrm{D}^{2} \times \mathrm{V}$ & 0.074 & -0.165 & 0.046 & -0.072 \\
\hline $\mathrm{D}^{3} \times \mathrm{V}$ & -0.0023 & 0.0053 & -0.0012 & 0.0015 \\
\hline$T \times D$ & 0.11 & -0.31 & --- & -0.42 \\
\hline $\mathrm{T} \times \mathrm{D}^{2}$ & -- & 0.018 & -0.0020 & 0.035 \\
\hline $\mathrm{T} \times \mathrm{D}^{3}$ & -- & $\ldots$ & -.- & -0.0008 \\
\hline $\mathrm{V} \times \mathrm{T} \times \mathrm{D}$ & -0.034 & --- & $-\cdots$ & m \\
\hline$n$ & 535 & 560 & 559 & 582 \\
\hline$R^{2}$ & 0.79 & 0.86 & 0.82 & 0.88 \\
\hline
\end{tabular}

${ }^{x}$ Temperatures were $10,17.5$, and $25 \mathrm{C}$. VPD ranged from 0.12 to $2.36 \mathrm{kPa}$.

"A "full" model was fitted with GLM procedures (SAS, 1985), and variables with significant $(P \leq$ $0.05)$ Type III SS were retained. If an interaction term was significant and contained one or more nonsignificant single-factor terms, the single-factor terms were retained in the reduced model.

${ }^{\times}$Units in $\mathrm{MPa}$; positive number. $\mathrm{MC}=$ percent, dry-weight basis.

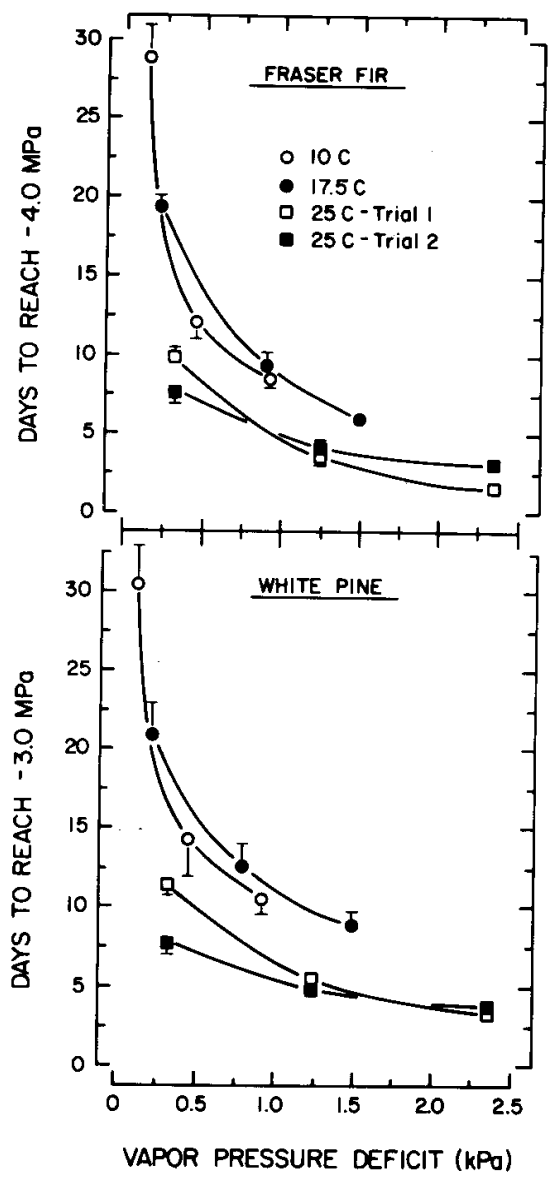

Fig. 1. Days (D) for Fraser fir and eastern white pine to reach $\psi=-4.0 \mathrm{MPa}$ and $-3.0 \mathrm{MPa}$, respectively, when dried in darkness at various temperatures $\left(\mathrm{T}={ }^{\circ} \mathrm{C}\right)$ and $\mathrm{VPD}(\mathrm{kPa})$. Trial $1: 0=10 \mathrm{C}, \bullet=17.5 \mathrm{C}, \square=25 \mathrm{C}$. Trial 2: $=25 \mathrm{C} . \mathrm{n}=6$; vertical bars $=$ SE. Missing SE bars were smaller than graph symbols. Fraser fir: $\mathrm{D}=10.22-0.35(\mathrm{~T})+$ $2.71(\mathrm{VPD})^{-1} ; R^{2}=0.92$. White pine: $\mathrm{D}=$ $14.0-0.44(\mathrm{~T})+2.56(\mathrm{VPD})^{-1} ; R^{2}=0.83$. controlled-environment chambers.

Treatments (Table 1) consisted of three temperatures $(10,17.5$, and $25 \mathrm{C})$ in combination with three relative humidities $(25 \%$, $60 \%$, and $90 \%$ ), imposed in darkness. The effect of fluorescent light (photosynthetic photon flux $=250$ to $290 \mu \mathrm{mol} \cdot \mathrm{s}^{-1} \cdot \mathrm{m}^{-2}$ ) was also evaluated at $60 \% \mathrm{RH}$. One trial was conducted for each treatment combination, using branches collected 9 and 27 Nov. 1989, and 2 Jan. 1990. Trees were dormant during this period, and the first two dates were within the harvest season for Christmas trees. A second trial was conducted at $25 \mathrm{C}$, beginning on 22 Feb. 1990.

$\psi$ was measured with a pressure chamber (PMS Instruments, Corvallis, Ore.), beginning when branches were first placed in chambers. Measurements were repeated after 4 to $6 \mathrm{~h}, 24 \mathrm{~h}, 48 \mathrm{~h}$, and often enough thereafter to determine the drying curve for each branch. Fresh weight of each branch was recorded initially and on each occasion when $\psi$ was determined. Measurements continued on Fraser fir until $\psi$ was less than or equal to $-4.5 \mathrm{MPa}$; on white pine until less than or equal to $-3.2 \mathrm{MPa}$. Then each branch was dried to constant weight at $65 \mathrm{C}$ and $\mathrm{MC}$ (dry-weight basis) calculated.

Each measurement of $\psi$ was carried out on a single needle, which allowed repeated measurements without destroying or significantly reducing the dry weight of branches. Usually, it was necessary to measure only one needle, particularly when branches had a relatively high MC. As branches dried, or if resin interfered, it was sometimes necessary to repeat measurements. Branches were outside the controlled-environment chambers $<15$ min during measurement.

Relative humidity was monitored continuously and maintained by heating chambers and injecting steam when necessary. Values occasionally fluctuated $\pm 3 \%$ or $4 \%$. The low $\mathrm{RH}$ was obtained by circulating air through a chemical drier.

Regression models were developed, using GLM procedures (SAS Institute, 1985) to predict water potential as a function of VPD, temperature, and duration of exposure. The analysis was carried out on a subset of observations representing $\approx 38 \%$ of the full set to eliminate successive observations with identical or similar values. Regressions were also used to determine the relationship between $\psi$ and branch MC, as well as the relationship of VPD to MC at $-4.0 \mathrm{MPa}$ and $-3.0 \mathrm{MPa}$ for Fraser fir and white pine, respectively.

Drying rates were affected by VPD and temperature (Fig. 1). Fraser fir dried in darkness at $10 \mathrm{C}$ and $90 \% \mathrm{RH}(\mathrm{VPD}=0.1 \mathrm{kPa})$ required $\approx 29$ days to reach $-4.0 \mathrm{MPa}$, compared to 2 to 3 days at $25 \mathrm{C}-25 \% \mathrm{RH}$ $(\mathrm{VPD}=2.36 \mathrm{kPa})$. Drying rates at $25 \mathrm{C}$ were faster than those at $10 \mathrm{C}$ and $17.5 \mathrm{C}$, which were similar across a range of VPD (Fig. 1). Regressions to estimate drying time for Fraser fir and white pine to reach -4.0 and -3.0 $\mathrm{MPa}$, respectively, explained $92 \%$ of the variation for Fraser fir and $83 \%$ for white pine (Fig. 1). The time required for white 


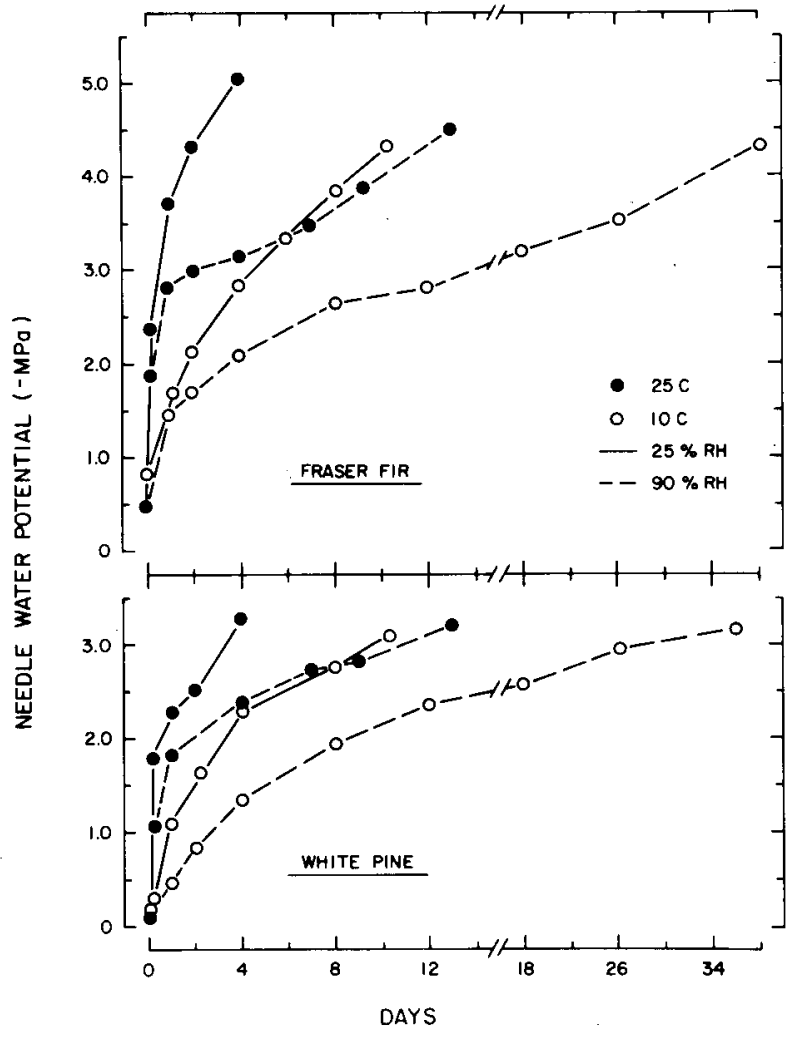

Fig. 3. $\psi$ of Fraser fir and eastern white pine dried in darkness at various temperatures and two relative humidities. $=25 \mathrm{C}, \bigcirc=10 \mathrm{C},(\stackrel{-}{-}=25 \% \mathrm{RH},(---)=90 \% \mathrm{RH} . \mathrm{n}=6$. The sE were usually $\leq 5 \%$ of the mean.

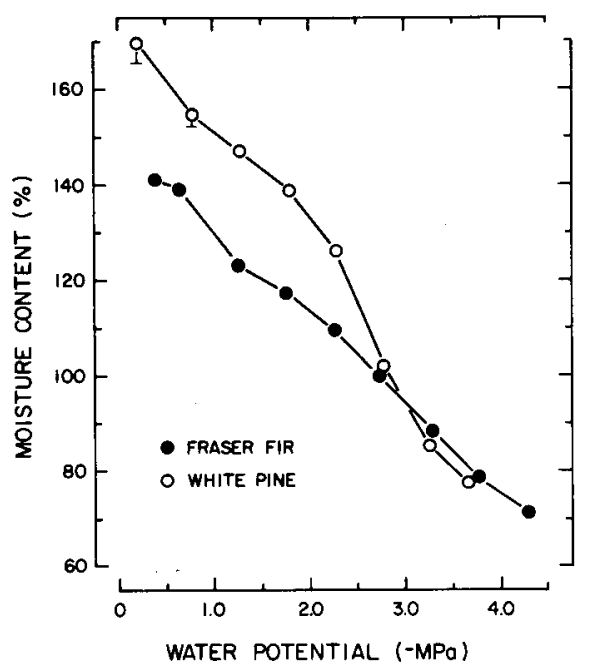

Fig. 4. Relationship of $\psi$ to branch $\mathrm{MC}$ for Fraser fir and eastern white pine. Fraser fir: $\mathrm{MC}=$ $147.0-1.72(\psi) ; R^{2}=0.90$. White pine: $M C$ $=172.6-1.37(\psi)-0.037(\psi)^{2} ; R^{2}=0.69$. Values represcnt means for intervals of $0.5 \mathrm{MPa}$. The number of observations for each data point was 18 to 141 . Missing SE bars were smaller than graph symbols.

pine to reach - 3.0 MPa was about the same as that for Fraser fir to reach $-4.0 \mathrm{MPa}$.

Light significantly increased drying rates for both species (Fig. 2). This effect was most pronounced at $17.5 \mathrm{C}$.

Regression models to predict $\psi$, as a function of temperature, VPD, and time, explained $79 \%$ to $88 \%$ of the variation (Table
2). Needle $\psi$ for Fraser fir initially averaged $-0.55 \mathrm{MPa}$ and decreased very quickly at 25C-25\% RH (Fig. 3). Branches subjected to $25 \mathrm{C}-90 \% \mathrm{RH}$ dried to $-2.8 \mathrm{MPa}$ in the 1 st day, followed by a marked decrease in water loss. Initial $\psi$ for white pine was -0.10 $\mathrm{MPa}$ (Fig. 3). In darkness, branches at 25C dried to $-1.8 \mathrm{MPa}$ in $24 \mathrm{~h}$, followed by a noticeable reduction in the rate of water loss at $25 \%$ and $90 \% \mathrm{RH}$. For both species, drying was much slower at $10 \mathrm{C}$.

$\mathrm{MC}$ of Fraser fir after initial hydration averaged $140 \%$ and decreased linearly to $75 \%$ at - 4.0 MPa (Fig. 4). Initial values for white pine averaged $170 \%$ and decreased linearly to $-2.2 \mathrm{MPa}$. Thereafter, the slope was more negative, with $\mathrm{MC}$ at $-3.0 \mathrm{MPa}$ averaging $90 \%$.

The MC of branches of Fraser fir at -4.0 $\mathrm{MPa}$ was a linear function of VPD during drying (Fig. 5); branches dried at 25C-25\% $\mathrm{RH}$ had an average $\mathrm{MC}$ of $84 \%$ at -4.0 $\mathrm{MPa}$, compared to $74 \%$ at $25 \mathrm{C}-90 \% \mathrm{RH}$. No such relationship was evident for white pine at 25C. VPD did not affect the critical $\mathrm{MC}$ of Fraser fir or white pine branches dried at $17.5 \mathrm{C}$ or $10 \mathrm{C}$.

Stomata respond to vapor pressure gradient, temperature, wind, and light (Lindsay, 1971; Schultze, 1986; Sheriff, 1979; Sowell, 1985), and close at different levels of stress, depending on species. This sharply reduces transpiration, usually before $\psi$ reaches $-2.4 \mathrm{MPa}$, but sometimes as low as -3.4 MPa (Fetcher, 1976; Hinckley et al., 1982; Lopushinsky, 1969; Puritch, 1973; Run- ning, 1976). Abies species have weaker stomatal control of transpiration than other conifers (Guehl and Aussenac, 1987; Lopushinsky, 1969; Running, 1976; Zobel, 1974). Because harvested Christmas trees cannot replenish transpired water, they progressively dry. Stomata eventually close, but transpiration continues, albeit at slower rates (Puritch, 1973). In this study, the point of stomatal closure for Fraser fir and white pine, based on changes of slope in the water loss curve, was approximately - 2.8 $\mathrm{MPa}$ and - 1.8 MPa, respectively (Fig. 3).

Our results clearly demonstrate the advantage of storing harvested trees at low temperature and low VPD. Any increase in VPD accelerated drying (Fig. 1). Raising postharvest temperature from 17.5 to $25 \mathrm{C}$ also accelerated drying, especially at low VPD. This difference was confirmed by the second trial at 25C. Even at $90 \% \mathrm{RH}$, trees at $25 \mathrm{C}$ reached the critical $\mathrm{MC}$ in about one-third the time required at $10 \mathrm{C}$. An added advantage of low temperatures is reduced respiration (Blankenship and Hinesiey, 1990).

The effect of low VPD might not be altogether positive. Increasing $\mathrm{RH}$ above $90 \%$ at $25 \mathrm{C}$ is risky, because a small temperature reduction at high vapor pressure can lead to condensation on plant surfaces, which, in time, can result in molding and massive needle drop. Low temperatures reduce this risk because the air contains less water vapor for any particular RH. In closed storage facilities, owing to transpiration, $\mathrm{RH}$ will probably be $\geq 90 \%$ early in storage for trees that occupy a significant volume of the storage space and when refrigeration coil and room temperature differ minimally.

Some trees were consistently unable to regulate water loss, especially at high VPD; others dried much more slowly. We have noted in other experiments that transpiration can vary up to $100 \%$ among trees, especially white pine. Other conifers also demonstrate substantial variation in transpiration among individuals (Meinzer, 1982; Newton et al., 1986).

Because the relationship between $\mathrm{MC}$ and $\psi$ at $-4.0 \mathrm{MPa}$ for Fraser fir is affected by VPD (Fig. 5), trees that dry at a low VPD, although requiring more time to reach the critical MC, will have a smaller residual moisture reserve at that point. Although it is not known how this affects dehydration, the possible disadvantage is probably greatly exceeded by the clear advantage of low VPD in slowing drying.

Moisture content decreased rapidly in the hours immediately after harvest. Fraser fir and white pine at 25C-90\% RH lost about one-half and one-third of their moisture reserve (quantity of water that can be lost before a tree reaches the critical MC), respectively, in the first 24 h (Figs. 3 and 4). At 10C-90\%RH, the time required to lose the same quantity of water was 12 and 7 days, respectively. Because trees contain a finite water reserve, they should be harvested when $\mathrm{MC}$ is highest, e.g., at night or in the morning. Trees should be transferred to dark or dimly lit storage areas as soon as 


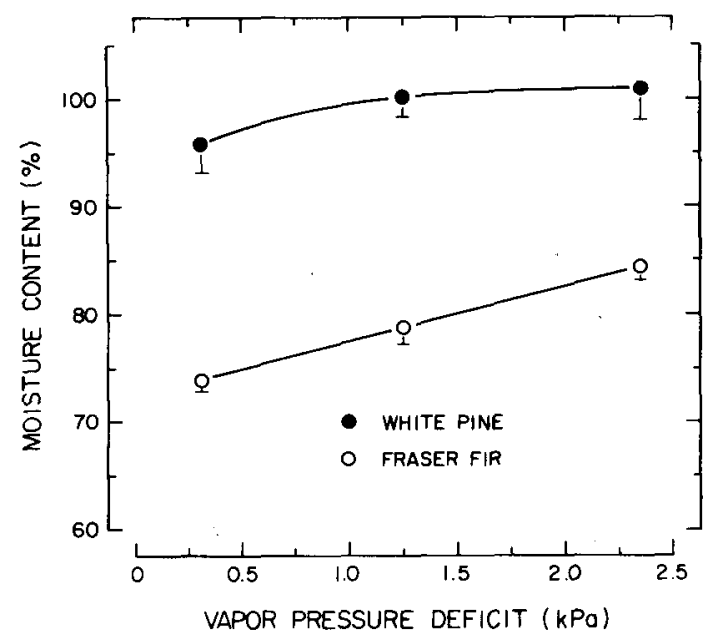

Fig. 5. MC (\%) of Fraser fir and eastern white pine at - 4.0 MPa and - 3.0 MPa, respectively, as affected by VPD during postharvest drying. Branches were dried in darkness at $25 \mathrm{C}$. Fraser fir: MC $=72.3+5.11(\mathrm{VPD}) ; R^{2}=0.76$. White pine: no significant regression. $\mathrm{n}=6$ : vertical bars $=$ SE.

possible after harvest, or at least shaded in the field after baling. Allowing recently cut trees to lie unbaled in warm, sunny weathereven for half a day-increases heat input (Sowell, 1985) and greatly reduces the stored moisture reserve, which increases the initial level of stress as trees enter the marketing stream.

\section{Literature Cited}

Blankenship, S.M. and L.E. Hinesley. 1990. Tolerance of controlled atmosphere storage of cut Fraser fir and its respiration rate in air. HortScience 25:941-943.

Chastagner, G.A. 1986. Effect of postharvest moisture stress on the keeping qualities of Douglas-fir Christmas trees. HortScience 21:485486.

Fetcher, N. 1976. Patterns of leaf resistance to lodgepole pine transpiration in Wyoming. Ecology 57:339-345.

Grange, R.I. and D.W. Hand. 1987. A review of the effects of atmospheric humidity on the growth of horticultural crops. J. Hort. Sci. 62:125-134. Guehl, J.-M. and G. Aussenac. 1987. Photosynthesis decrease and stomatal control of gas exchange in Abies alba Mill. in response to vapor pressure difference. Plant Physiol. 83:316-322.

Hinckley, T.M., R.O. Teskey, R.H. Waring, and Y. Morikawa. 1982. The water relations of true firs, p. 85-92. In: C.D. Oliver and R.M. Kenady (eds.). Proc. Biol. Mgmnt. of True Fir in the Pacific Northwest Symp. Seattle-Tacoma, Wash., 24-26 Feb. 1981. U.S. Dept. Agr. For. Serv., Pacific NW For. Range Expt. Sta.

Hinesley, L.E. 1984. Measuring freshness of cut Fraser fir Christmas trees. HortScience 19:860862.

Hinesley, L.E. 1988. Water relations of cut eastern redcedar Christmas trees. HortScience 23:589-591.

Lindsay, J.H. 1971. Annual cycle of leaf water potential in Picea engelmannii and Abies lasiocarpa at timberline in Wyoming. Arctic Alpine Res. 3:131-138

Lopushinsky, W. 1969. Stomatal closure in conifer seedlings in response to leaf moisture stress.
Bot. Gaz. 130:258-263.

Meinzer, F.C. 1982. The effect of vapor pressure on stomatal control of gas exchange in Douglasfir (Pseudotsuga rnenziesii) saplings. Oecologia (Berlin) 54:236-242.

Mitcham-Butler, E. J., L.E. Hinesley, and D.M. Pharr. 1988. Effects of harvest date, storage temperature, and moisture status on postharvest needle retention of Fraser fir. J. Env. Hort. 6:14.

Montano, J.M. and W.M. Proebsting. 1985. Effects of drying on cut Douglas-fir. J. Amer. Soc. Hort. Sci. 110:751-757.

Newton, R.J., C.E. Meier, J.P. Van Buijtenen, and C.R. McKinley. 1986. Moisture-stress management: silvicuhure and genetics, p. 3560. In: T.C: Hennessey, P.M. Dougherty, S.V. Kossuth, and J.D. Johnson (eds.). Stress physiology and forest productivity. Martinus Nijhoff, Boston.

Puritch, G.S. 1973. Effect of water stress on photosynthesis, respiration, and transpiration of four Abies species. Can. J. For. Res. 3:293-298.

Running, S.W. 1976. Environmental control of leaf water conductance in conifers. Can. J. For. Res. 6:104-112.

SAS Institute. 1985. SAS user's guide: Statistics. version 5 (ed.). SAS Institute, Inc., Cary, N.C.

Schulze, E.-D. 1986. Carbon dioxide and water vapor exchange in response to drought in the atmosphere and the soil. Annu. Rev. Plant Physiol. 37:247-274.

Seiler, J.R., T.J. Nichols, and D.J. Paganelli. 1988. Dehydration characteristics of cut white pine and Norway spruce Christmas trees. HortScience 23:164-166.

Sheriff, D.W. 1979. Stomatal aperture in the sensing of the environment by guard cells. Plant Cell Env. 2:15-22

Sowell, J.B. 1985. Winter water relations of trees at alpine timberline, p. 71-77. In: H. Turner and W. Tranquillini (eds.). Establishment and tending of subalpine forest: research and management. Proc. 3rd Intl. Union For. Res. Organizations (IUFRO) Workshop, 1984

Van Wagner, C.E. 1963. Flammability of Christmas trees. Can. Dept. For. Publ. 1034.

Zobel, D.B. 1974. Local variation in intergrading Abies grandis-Abies concolor populations in the central Oregon Cascades: II. Stomatal reaction to moisture stress. Bot. Gaz. 135:200-210. 